\section{Bacillus cereus intoxication followed by periorbital oedema}

Since 1971 over 30 incidents of Bacillus cereus intoxication have been reported in the U.K. Outbreaks in other European countries reported since 1950 have differed in their incubation period and symptoms from those in the U.K., the vehicles tending to be dairy products and sauces, as opposed to reheated rice in the U.K. B. cereus has also been shown to be a pathogen in: endocarditis in a heroin addict, which responded to clindamycin $;^{1}$ pneumonia with pulmonary necrosis in a patient with subacute lymphatic leukaemia $;^{2}$ post-traumatic purulent meningitis; ${ }^{3}$ and bacteraemia in patients undergoing intermittent dialysis. $^{4}$

\section{Case Report}

An 18-year-old girl presented with vomiting and central abdominal colic, beginning four hours after eating a Chinese meal which included boiled rice, followed in one hour by tenesmus, diarrhoea, and finally tetany. There was no history of any gastrointestinal disturbance or drug ingestion. The patient was distressed and grossly dehydrated; hands formed the posture of "main d'accoucheur," Chvostek's and Schulze's signs were strongly positive, the tendon reflexes were uniformly brisk, and breathing was rapid and shallow. She was tender in the left iliac fossa, bowel sounds were increased, diarrhoea was profuse and watery, and she had intermittent dry retching and vomiting. No periorbital oedema was noted, and the patient was afebrile.

The results of biochemical investigation before treatment were as follows: Serum sodium was $142 \mathrm{mmol} / 1$, potassium $4.3 \mathrm{mmol} / \mathrm{l}$, bicarbonate 22 $\mathrm{mmol} / \mathrm{l}$, calcium $2.56 \mathrm{mmol} / 1(5.12 \mathrm{mEq} / \mathrm{l})$, phosphate $0.4 \mathrm{mmol} / 1(1.2 \mathrm{mg} /$ $100 \mathrm{ml})$, and blood urea $5 \cdot 1 \mathrm{mmol} / 1(30 \cdot 7 \mathrm{mg} / 100 \mathrm{ml})$. Arterial $\mathrm{pH}$ was $7 \cdot 55$, $\mathrm{PCO}_{2} 3.2 \mathrm{kPa}(24 \mathrm{~mm} \mathrm{Hg}), \mathrm{Po}_{2} 13.6 \mathrm{kPa}(102 \mathrm{~mm} \mathrm{Hg})$, and standard bicarbonate $25 \mathrm{mmol} / \mathrm{l}$.

Rebreathing air from an inflatable bag, together with intramuscular diazepan i, stopped the tetany in 15 minutes. Six litres of normal saline solution had to be given over 18 hours, together with $6 \mathrm{~g}$ of potassium over the next three days. Vomiting settled within ten hours, and diarrhoea within 15 hours of admission. Three hours after admission the patient developed fever, her temperature rising to $38.9^{\circ} \mathrm{C}$ after nine hours and falling to normal after 15 hours. Twelve hours after admission bilateral periorbital oedema appeared and lasted eight hours, remitting without any treatment. After three days the patient was discharged home well and on no therapy.

Stool samples were cultured on blood agar aerobically and anaerobically, with and without Robertson's meat broth; on deoxycholate citrate agar, with and without selenite; on McConkey's agar and on salt agar. A sample taken two days after admission grew no organism, but that taken on admission showed a heavy growth of $B$. cereus. Neither of the stool samples grew salmonella, Clostridium welchii, Staphylococcus aureus, or any other pathogen.

\section{Comment}

Periorbital oedema accompanying $B$. cereus intoxication does not appear to have been recorded, and this case may have represented a Type III allergic reaction to the toxin. Thus fever, which rarely occurs in this intoxication, may have been related to this reaction. No signs of overhydration (which could account for periorbital oedema) were present at any stage.

$B$. cereus may often be missed as the aetiological agent in many cases of food poisoning. It is important to suspect this condition in all cases of food poisoning after eating rice, so that public health authorities may take prompt action to prevent an epidemic. In Britain the most likely source of $B$. cereus is uncooked rice. The spores survive reheating, boiling, and frying, and ideally multiply during nonrefrigerated storage. ${ }^{5}$ The occurrence of the intoxication specifically in Chinese restaurants is explained by the reluctance of Chinese restaurateurs to refrigerate rice left over for serving again since refrigeration may cause the grains to stick together on reheating.

I thank Dr. R. J. Wilson for permission to report on the patient under his care and for his advice and Dr. R. D. Montgomery for his advice.

1 Craig, C. P., Annal of Internal Medicine, 1974, 80, 418.

2 Coonrod, J., Leadley, P., and Eickhoff, T., American Review of Respiratory Diseases, 1971, 103, 711.

3 Basila, V. F., Zeitschrist für die gesamte innere Medizin und ihre Grenzgebiete, 1966, 21, 717.

Curtis, J. R., Lancet, 1967, 1, 136.

${ }^{5}$ Hobbs, B. C., Postgraduate Medical fournal, 1974, 50, 597.

Solihull Hospital, Lode Lane, Solihull, West Midlands B91 2JL B. J. GUTKIN, M.B., в.сH., Senior House Officer

\section{Circulatory collapse after oral oxprenolol}

Beta-adrenergic blocking agents are used in the treatment of hypertension, angina, and various disturbances of cardiac rhythm. They may impair cardiac function by removing sympathetic tone from an already compromised myocardium, and the provocation or worsening of heart failure is a well recognised complication of such therapy. ${ }^{1}$ An impression that beta-blockers such as oxprenolol which possess intrinsic sympathomimetic activity are less likely to impair cardiac function than blockers such as propranolol which lack this property gains strength from the absence of reports of serious circulatory depression after oxprenolol.

\section{Case Report}

A 58-year-old man had been in controlled left ventricular failure and on maintenence therapy with digoxin $0.5 \mathrm{mg}$ and frusemide $40 \mathrm{mg}$ daily since a myocardial infarction two years previously. For a week before admission he had become progressively more breathless on exertion and orthopnoeic. On examination he was in atrial fibrillation (having previously been in sinus rhythm) with a heart rate of $125 / \mathrm{min}$ and his blood pressure was $110 / 80 \mathrm{~mm} \mathrm{Hg}$. The venous pressure was raised $6 \mathrm{~cm}$, the heart clinically enlarged, and a third sound was audible at the apex. Crepitations were present in both lungs and there was slight peripheral oedema. The ECG showed atrial fibrillation with a ventricular rate of $110-135 / \mathrm{min}$; many bizarre QRS complexes, probably ventricular in origin; and changes of old anteroseptal infarction. Chest $x$-ray films showed an enlarged heart with pulmonary venous hypertension and interstitial oedema; serum digoxin level was $4 \cdot 2 \mathrm{nmol} / 1(3.3 \mathrm{ng} / \mathrm{ml})$; electrolytes, urea, serial cardiac enzymes, and thyroid function tests were normal.

Despite the rapid ventricular rate he seemed digoxin toxic and the dose was reduced to $0.375 \mathrm{mg}$ daily. The heart failure responded to an increased dose of frusemide, but a week later he still required $120 \mathrm{mg}$ daily and his heart rate remained between 110 and $130 / \mathrm{min}$. To slow this rapid ventricular response a trial dose of oxprenolol $20 \mathrm{mg}$ was given by mouth. After 40 minutes he became confused, cold, deeply cyanosed, drenched in sweat, and his blood pressure rapidly fell to an unrecordable level with imperceptible peripheral pulses. He remained in atrial fibrillation and the ventricular rate had fallen only to $80 / \mathrm{min}$. An immediate injection of glucagon $2 \mathrm{mg}$ had no effect. Atropine $1.2 \mathrm{mg}$ intravenously caused no increase in heart rate or other benefit. Isoprenaline was infused intravenously in an initial dose of $5 \mu \mathrm{g} / \mathrm{min}$, which was doubled every few minutes until after 15 minutes he was receiving $40 \mu \mathrm{g} / \mathrm{min}$; he was then given $10 \mathrm{ml}$ of $10 \%$ calcium gluconate. His circulation began to improve rapidly and in a short time he was fully recovered. Isoprenaline was continued at a reduced rate of $10 \mu \mathrm{g} / \mathrm{min}$ for a further 4 hours. There were no subsequent ECG or enzyme changes.

\section{Discussion}

There is some evidence that oxprenolol has less effect in reducing left ventricular contractility than propranolol, ${ }^{2}{ }^{3}$ and the only previous reports of severe haemodynamic disturbance after beta-blockade concerned the intravenous administration of propranolol. ${ }^{4} \mathrm{~A}$ trial dose of oxprenolol was thought to be safe in this case despite the history of cardiac failure since the failure had been controlled and the patient was fully digitalised. That profound cardiac depression occured at a ventricular rate of $70-80 / \mathrm{min}$ suggests that it resulted from an acute impairment of function.

This case emphasises the need for extreme care in using any beta-blocking drug when myocardial performance is impaired. It also shows that serious circulatory depression, should it occur, may be treated effectively with isoprenaline provided it is given promptly and in sufficiently high dosage to overcome the betablockade.

I thank Dr J F Dow for permission to publish details of the patient under his care, and Dr B F Robinson and Dr J G Collier for their helpful criticism and advice.

1 Stock, J P P, and Dale, N, British Medical fournal, 1963, 2, 1230.

2 Grandjean, T, and Rivier, J L, British Heart fournal, 1968, 30, 50.

3 Choquet, Y, et al, American fournal of Cardiology, 1972, 29, 257.

* Stephen, S, American fournal Cardiology, 1966, 18, 463.

Department of Medicine, St George's Hospital, London SW1 NICHOLAS H BROOKS, MB, MRCP, Registrar 